\title{
Kesetaraan Gender danPergulatan Status SosialWanita Bali dalamKonstelasiPolitikPraktis
}

\author{
Desak PutuParmiti \\ TeknologiPendidikan, FakultasIlmuPendidikan, UniversitasPendidikanGanesha, Indonesia
}

\begin{abstract}
Keyword
Abstract:This study aims to examine: the profile of Balinese women in practical political constellation, the draft $s:$ model of gender-based political education, models for women in politics, scientific articles published in accredited journals. The research was analyzed by using descriptive qualitative analysis technique, and statistic analysis. The

political educatio conclusions of this research, namely: 1) the role of political participation of women tends to be low. (2) The position and participation of women in political activity is highly marginalized. (3) The climate and communication patterns n; of family life, culture, official villages, and schools do not support the process of political education for indigenous balinese women; gender equality; practical wom to achieve improvement (4) Indigenous village as the highest symbolism in the level of indigenous peoples structurally has not done any real activity in relation to political education on women. (5) The process of forming Indonesian civil society, in relation to the objectives and characteristics of indigenous peoples of indigenous Balinese villages, is quite relevant in creating a gender equality climate.
\end{abstract} politics

\begin{abstract}
Abstrak:Penelitianini bertujuan untuk melihat: profilwanitabalidalamkonstelasipolitikpraktis, draft model pendidikanpolitik yang berbasiskesetaraan gender, draft model pengarusutamaan gender bagiwanitabalidalambidangpolitik, artikelilmiah yang terbit di jurnalterakreditasi. Penelitiandianalisisdenganmenggunakanteknikanalisiskualitatifdeskriptif, dananalisis statistic. Simpulandaripenelitianini, yaitu: 1) peranpartisipasipolitikperempuanbalicenderungrendah. Kedudukandanperansertakaumperempuandalamaktivitaspolitiksangattermarginalkan. Iklimdanpolakomunikasikehidupankeluarga, desaadat, desadinas, dansekolahtidakmendukung proses pendidikanpolitikbagikaumperempuanbaliasliuntukmencapaipeningkatan. (4) Desa adat sebagai simbolisme tertinggi dalam tataran masyarakat bali asli, secara struktural belum melakukan aktivitas nyata dalam kaitannya dengan pendidikan politik pada kaum wanitanya.(5) Proses pembentukkanmasyarakatmadani Indonesia, dalamhubungannyadengantujuandankarakteristikmasyarakatDesaAdatbaliasliternyatacukuprelevandalammencipta kaniklimkesetaraan gender.
\end{abstract}

Kata

kunci: pendidik an politik; wanita bali;

kesetaraa

n gender;

politik

praktis

AlamatKorespondensi:

E-mail: dp-parmiti@undiksha.ac.id (DesakPutuParmiti)

\section{Pendahuluan}

Perjuangan untuk mengarusutamakan kesetaraan hubungan kekuasaan antara perempuan dan laki-laki (gender) dalam birokrasi dengan upaya mengubah kebijakan bukan hal yang mudah. Apalagi kalau hal itu menyangkut nilai-nilai tertentu agama yang diyakini sebagai kebenaran tunggal. "Saya menerima banyak ancaman dan teror, serta kemandekan karier. Tetapi, saya tidak mundur," ungkap Farisa (2006), peneliti dan anggota Kelompok Kerja Pengarusutamaan Gender Departemen Agama dalam sebuah seminar tentang gender dalam format birokrasi. Selanjutnya dikatakan pula bahwa: "sebenarnya banyak kitab lama yang mendukung kesetaraan, tetapi itu tak pernah dimunculkan." Dengan demikian, interpretasi agama dapat dijadikan alat politik untuk melakukan dominasi terhadap kelompok tertentu.

Sejarah telah mencatat, begitu berat dan berlikunya perjuangan kaum perempuan untuk mampu "mensejajarkan diri" dengan kaum laki-laki dalam sebuah komunitas. Sejak 350 tahun sebelum masehi, Aristoteles, dalam risalahnya yang berjudul "Politik", menyatakan wanita, begitu juga anak-anak dan budak-budak tidak termasuk sebagai warga negara. Fakta ini telah terwariskan berabad-abad lamanya dalam konstalasi masyarakat, sehingga kaum perempuan tetap menjadi warga kelas dua di tengah-tengah kemajuan masyarakatnya. Kaum laki-laki yang dipertegas oleh statemen beberapa tokoh, menempatkan bahwa kaum perem-puan memiliki perbedaan yang sangat tajam dalam hal ke-intelektualan (Misbah, 2000), disamping juga karena alasan fisik dan ketidak mampuan wanita untuk menyelesaikan masalah-masalah di sekitarnya. 
Pintu "kesetaraan mulai terbuka" manakala sejarah sovinisme laki-laki mulai terancam, dengan lahirnya berbagai gerakan kaum perempuan yang dimulai di kawasan Amerika dan Eropa, yang akhirnya melahirkan berbagai dilema di tengah-tengah masyarakat. Di dunia Barat terdapat gerakan feminisme, yang dapat di golongkan menjadi tiga, yakni kaum feminis liberal, kaum fiminis radikal, dan kaum feminis sosialis (Moraless, 2004). Tujuannya menyadarkan kaum wanita akan hak-haknya dan mereka harus menuntut emansipasi, dilakukan dengan cara menghadapi kaum laki-laki.Fokus utama dari penelitian ini adalah: pengembangan model pendidikan politik dan pengarusutamaan gender kaum wanita dalam bidang politik, khususnya bagi masyarakat pedesaan di Provinsi Bali. Terkait dengan hal tersebut, maka secara rinci, tujuan khusus dari penelitian ini dapat dijabarkan sebagai berikut: (1) Mengidentifikasi, memformula-sikan, dan memetakan konsep dasar pendidikan politik yang telah dan sedang dilaksanakan oleh pemerintah daerah, lembaga politik, lembaga adat, dan lembaga swadaya masyarakat, baik yang bersifat terprogram maupun bersifat personal (need assesment). (2) Merumuskan dan mengintegrasikan karakteristik sosial-budaya, dan kebutuhan k kaum wanita Bali dalam bidang politik, sehingga terwujud pemahaman dan kesadaran optimal pada kaum wanita pedesaan, tentang konsep dan praktek politik di wilayahnya masing-masing. (3) Mengembangkan pendekatan baru untuk pemberdayaan kaum wanita dalam bidang politik, dengan mengakomodasi eksistensi lembaga-lembaga lokal, nilai-nilai budaya masyarakat setempat, kebutuhan dan orientasi politik masyarakat setempat, dan lembaga formal pemerintah daerah kabupaten/kota setempat. (4) Mengembangkan model rekayasa sosial pemberdayaan kaum wanita pedesaan dalam bidang politik, dengan pelibatan desa adat sebagai simbolisme kekuatan dan keutuhan desa adat di setiap masyarakat Hindu Bali. (5) Membangun jejaring sosial bagi pengentasan buta politik dikalangan masyarakat pedesaan di Bali, melalui sinergi potensi dan sumber daya antara dunia kampus (institusi peneliti, desa adat, pemerintah daerah kabupaten/kota, dan lembaga swadaya masyarakat yang ada di masing-masing lokasi penelitian.

Pada seminar tentang: "Perempuan dalam Format Birokrasi", disimpulkan bahwa: ...selama ini hukum telah dijadikan alat untuk mendefinisikan kekuasaan kelompok-kelompok tertentu sehingga membatasi ruang gerak perempuan, tidak responsif terhadap persoalan-persoalan perempuan, termasuk kejahatan terhadap kemanusiaan perempuan (Sulistyowati, 2006). Isu perempuan, sangat rentan untuk dimasuki dan dijadikan isu politik karena simbolisasi politik dilekatkan pada seksualitas tubuh dan keberadaan perempuan. Bertalian dengan hal itu, Farisa (2006), seorang peneliti sosial yang fokus pada masalah-masalah perempuan, mengingatkan pentingnya pembaharuan hukum untuk "meraih kesetaraan gender", tetapi harus diwaspadai bila hukum yang dirancang sarat dengan kepentingan untuk menguasai.

Keterbukaan peran kaum perempuan dalam kontes politik, pertama kali muncul dan termaknakan dalam syariah Islam, yang menjelaskan aturan-aturan syariah mengenai kaum laki-laki dan kaum perempuan (Ansyar, 2006). Namun fakta tersebut belum bisa diterjemahkan sebagai "perlakuan kesetaraan" antara laki-laki dan perempuan dalam pentas politik. Syariah tersebut baru mencerminkan bahwa ada masalah kesetaraan antara kaum laki-laki dan kaum perempuan dalam dunia politik, yang membutuhkan solusi. Menurut Ansyar (2006), pertanyaan tentang kesetaraan atau kurang sejajarnya antara laki-laki dan wanita bukanlah hal yang patut untuk didiskusikan dalam dunia Islami, karena hal tersebut merupakan sebuah ekspresi yang tidak terdapat dalam perundang-undangan Islam.Bertalian dengan preposisi yang dikedepankan oleh Ansyar di atas, Farisa (2006) menyatakan bahwa persamaan antara laki-laki dan wanita dalam dunia politik, bukanlah persoalan untuk diperdebatkan, bukan juga persoalan yang merupakan subjek dalam sistem sosial Islam. Menurut Farisa (2006) wanita menjadi setara dengan laki-laki, ataupun laki-laki menjadi setara dengan wanita di mata politik, bukanlah urusan penting, yang mana telah berpengaruh kepada kehidupan sosial secara luas, dan bukan pula merupakan fenomena yang seharusnya terdapat dalam kehidupan Islam. Tapi adalah sebuah ungkapan yang hanya ada di dunia Barat. Kondisi psikologis ini, sama sekali tidak ditemukan pada komunitas muslim, kecuali bagi mereka yang meniru budaya barat, yang berarti telah melanggar hak-hak alamiah wanita itu sendiri dalam kapasitasnya sebagai manusia. Phenomena tersebut bagi sebagian kalangan penganut pola pikir barat, menyebutnya sebagai restitusi (pemulihan) hak-hak yang sebelumnya memang belum terpulihkan (Ansyar, 2006).

Sejalan dengan generalisasi mengenai kesetaraan gender dalam dunia politik sebagaimana digambarkan di atas, masyarakat Bali Age yang merupakan sebuah komunitas yang terlepas dari "trah atau keturunan emigran Majapahit" telah meyakini bahwa para wanitanya, seperti halnya dengan kaum laki-lakinya adalah komunitas yang harus selalu berpikir dan bertindak untuk kepentingan komunitas dan keyakinan hakikinya, sehingga persoalan-persoalan lainnya termasuk politik akan mengikuti dan disesuaikan dengan kondisi serta kepentingan yang mengiringi (Arga, 2003). Memperkuat fakta ini, masyarakat Bali saat ini memposisikan wanita sebagai sebuah mahluk yang sejajar dan setara di mata Sang Pencipta, sehingga wanita juga diperkenankan dan didorong untuk ikut serta dalam perpolitikan selama hal itu tidak membahayakan tugas utamanya sebagai istri dan ibu. Sejalan dengan hal ini, Islam 
juga memperkenankan seorang perempuan untuk berpartisipasi dalam politik, sepanjang tidak mengabaikan tugas pokoknya sebagai pendamping suami. Dalam islam, itu merupakan kewajiban wanita untuk menyampaikan dakwah dan melaksanakan aturan atau pemerintahan (Ansyar, 2006). Bagaimanapun kontribusi wanita menurut syariah Islam, tidaklah dapat disamakan seperti laki-laki.

\section{Metode}

Penelitian ini dilihat dari pendekatannya menggunakan pendekatan "Critical Etnography Research" dalam paradigma penelitian kualitatif (Anderson, 1989) yang mengedepankan riset sosial sebagai bentuk kritik sosial dan budaya masyarakat (Miles dan Huberman, 1992). Melalui pendekatan ini akan dibentuk relasi sistem dengan menggunakan kekuatan menganalisis dan mensintesis keterkaitan antara tindakan, pengalaman subjektif, dan kondisi sosial yang terkait langsung dengan permasalahan penelitian yaitu rekonstruksi pengarusutamaan gender dalam politik praktis dalam suatu deskripsi dan narasi yang aktual, komprehensif, kontekstual, holistik, dan bermakna.Lokasi penelitian ini adalah di Provinsi Bali, khususnya pada desa-desa adat tradisional yang ada di Provinsi Bali. Pemilihan lokasi penelitian tersebut, lebih didasarkan pada upaya pemenuhan dan komprehensivitas data terkait dengan fokus masalah penelitian, sehingga nantinya dapat dirumuskan rekonstruksi dan formulasi gender dalam konteks politik di setiap daerah penelitian, dan mencerminkan konstruk masyarakat Bali secara menyeluruh. Sesuai dengan jenis data yang diperlukan dalam penelitian ini, maka pengumpulan data dalam penelitian ini menganut prinsip "peneliti adalah instrumen penelitian yang utama" ((Bogdan\&Taylor, 1975). Namun dalam pelaksanaannya, peneliti juga akan menggunakan beberapa alat pengumpul data bantuan. Sesuai dengan jenis pendekatan dan karakteristik penelitian, maka analisis data dalam penelitian ini akan dilakukan secara terus menerus dari awal hingga akhir keseluruhan proses penelitian.Secararinci proses analisis data dalampenelitianiniakanmengikutitahapantahapananalisispenelitianCritical Etnography ResearchdariCarspecken (1996), yang meliputipreliminary steps, yaitu: (1) compiling primary records, (2) preliminary reconstructive analysis, (3) dialogical data generation, (4) describing system relations, and (5) system relations as explanations of findings

\section{HasildanPembahasan}

Dominasi kekuasaan dan peranan politik laki-laki dalam struktur linggih desa tegak dan struktur pemerintahan Desa Adat bali sebagaimana yang dideskripsikan di Bab IV tidak dapat dilepaskan dari jalinan sistem nilai yang mendasari kehidupan sosial budaya masyarakat bali sebagai masyarakat religius yang memang menganut sistem hukum dan budaya patriakat. Ini berarti bahwa dalam realitas sosialbudaya masyarakat bali, dominasi kaum laki-laki mendapat legitimasi yang sangat tinggi. Dominasi tersebut sangat menonjol dalam berbagai bidang kehidupan, baik dalam tataran keluarga, masyarakat adat, dan pemerintahan desa. Konsekuensi dari budaya patriarki yang melekat dalam kehidupan masyarakat desa adat, tampaknya terbawa juga dalam struktur pemerintahan desa dinas (administratif). Hal ini dapat dilihat dalam struktur pemerintahan desa dinas, dimana hanya ada 2 (dua) orang perempuan yang menduduki jabatan sebagai kepala urusan (kaur), sedangkan selebihnya diisi oleh kaum laki-laki. Realitas ini merupakan salah satu bukti, bahwa perempuan di Desa Adat bali sangat termarginalkan dalam bidang kehidupan publik.

DalamkitabsuciWeda secaraumumtidakdisebutkanadanyaparameter martabatseseorangberdasarkanjeniskelaminataukelahirannya.

SebuahmantramdalamRgvedamenyebutkan, "Stri hi Brahma babhuvitha", wanitasesungguhnyaadalahseorangsarjanadanpembimbing VIII.33.19).selanjutnyadisebutkandalamBhagawadgita,

"kirtihSrirvak (Rgveda cha narinamsmritirmedhadhritihkshama." Artinya, di antarasifat-sifatwanita, Akuadalahkemasyuran, kemakmuran, kehalusanbudibahasa, kesenangan, kecerdasan, keteguhanhati, dankesabaran (Bhg. X:34). BerdasarkankitabSuci di atasjelaslahwanitamempunyaikedudukan yang terhormat.

Masyarakatbaliaslisebagaisebuahkomunitas yang memilikipoladandinamikakehidupansosial-budayatersendiri. Keluargasebagai unit sosialterkecildalamstrukturpemerintahandesaadat, merupakansuatuinstitusipertamadanutama yang menjadi media bagisetiapanggotamasyarakatbaliaslidalammengenallingkungansosialdanbudayanya. Artinya, melaluiinstitusikeluargalahseseorangakanmengenallingungansosialdanbudayamasyarakatnyasecaralebih luas. Dalamkehidupankeluarga, merekaakandiperkenalkandandibelajarkanberbagaikonsepdasarmengenainilai, norma, danadatistiadat yang harusdihormatidandilaksanakan di masyarakat. Hal inisejalandenganapa yang 
diketengahkanolehseorangpakarpendidikan

Bali,

yaituDantes

(1989), bahwakeluargamerupakanlingkunganpertamadanutamabagianakdalammemperolehpendidikankepribadi andanpendidikansosialsertaberbagaiketerampilanbekalhidup yang lain.

Masyarakat bali asli merupakan suatu institusi adat yang bersifat otonom. Artinya, bahwa mereka memiliki aturan main dan kewenangan yang bersifat utuh dalam mengatur dan memberdayakan segala potensi yang dimiliki oleh desa adat itu sendiri. Warga bali asli sebagai sebuah komunitas yang hidup dalam tatanan budaya yang diwarnai oleh idiologi patriarki, memiliki seperangkat hak dan kewajiban. Sebagai anggota krama desa adat, setiap kepala keluarga (keluarga batih), berhak menikmati tanah parumandesa, dalam bentuk karang paumahan, tegalan, dan kuburan. Perolehan hak tersebut harus diimbangi dengan melaksanakan kewajiban tertentu yang dibebankan oleh desa adat kepada setiap warga desa adat.

Menurut Awig-awig Desa Adat bali asli, krama desa adat memiliki sejumlah kewajiban, yaitu mentaati segala kaidah yang diberlakukan di lingkungan desa adat sehingga terwujud masyarakat yang tertib berdasarkan idiologi Tri Hita Karana. Di dalam konteks ini tercakup beberapa dimensi, yaitu: (1) sukerta tata pawongan, yaitu keharmonisan hubungan antara manusia dengan manusia, (2) sukerta tata palemahan, yaitu keharmonisan hubungan antara manusia dengan lingkungan alam, dan (3) sukerta tataparhyangan, yaitu keharmonisan hubungan antara manusia dengan para desa atau Sang Pencipta.

MasyarakatDesaAdatbaliaslisebagaimanahalnyamasyarakat lain di Indonesia sedangberprosessecara gradual danberkelanjutandalamrangkamembangunmasyarakat Indonesia baruyaitumasyarakatmadani. Seiring dengan proses reformasi di Indonesia, masyarakat Indonesia kini memasuki proses masyarakat madani. Masyarakat madani bukanlah sesuatu yang dikonsepsi atau digagas, apalagi gagasan import, melainkan sebagai dinyatakan oleh Suseno (dalam Jacob, 2000), adalah suatu masyarakat yang secara faktual, bukan normatif, dikehendaki atau dicita-citakan seiring dengan proses perubahan masyarakat Indonesia dalam gerakan masyarakat sipil (civil society).

Masyarakat bali asli sebagai bagian dari unit pembangunan, khususnya sebagai masyarakat pedesaan yang memiliki seperangkat potensi yang bisa dikembangkan, juga mengalami proses dan gerakan cita-cita masyarakat madani, sehingga dalam menganalisis gerakan-gerakan masyarakat sipil dalam lingkungan masyarakat Indonesia umumnya dan pada kelompok masyarakat tertentu, masalahnya bukanlah pada apakah kelompok masyarakat tersebut memahami atau memiliki konsep masyarakat madani atau apakah masyarakat tersebut setuju dengan konsep masyarakat madani, melainkan adalah adakah masyarakat madani tercermin dalam kehidupan masyarakat tersebut, sejauh mana, dan apa implikasi-implikasinya. Oleh karena itu dalam kaitannya dengan proses masyarakat madani pada masyarakat bali asli akan dikaji pula masalah-masalah di atas. Ditinjau dari tujuan atau cita-cita masyarakat bali asli dan dari sendi-sendi dinamika kehidupan masyarakat mereka dalam relevansinya dengan cita-cita dan gerakan masyarakat madani Indonesia.

\section{Simpulan}

Berdasarkankeseluruhan proses

makadiperolehbeberapahalpentingberkaitandenganpengarusutamaan

dalambidangpolitikpadamasyarakatbaliaslisebagaisimpulandaripenelitianini,

Dilihatdaripolakomunikasidanaktivitaskesehaianmasyarakatdesaadat, peranpartisipasipolitikperempuanbalicenderungrendah.

inibanyakdikontribusiolehpenerapanidiologipatriarki, $\quad$ yaitusuatuidiologikekerabatan menempatkankaumlaki-lakisebagaisentralkepemilikanhakdankewajiban-

kewajibanpublikdalamtatarankehidupansehari-har perempuanmerupakansubordinasi.Kecenderungankedudukan tersubordinasiinidapatdiketahuidari proses

sehinggakedudukandan status danperanperempuan yang sejarahperkembanganDesaAdatbaliasli,

kedudukandanperanperempuandalamstrukturdansistempemerintahandesaadat.

Kedudukandanperansertakaumperempuandalamaktivitaspolitiksangattermarginalkan,

kecualidalambeberapaaspek yang

sebagaimanadapatdilihatdalammaknasimbolis

yang

masihadadalamlingkuplingkungankeluarga,

Kedudukanwanitasecarapolitis, sangattermarginalkan, baikdalamlingkupkeluarga, desaadat, maupunaktivitaspolitikpraktis. (3) Iklimdanpolakomunikasikehidupankeluarga, desaadat, desadinas, dansekolahtidakmendukung pendidikanpolitikbagikaumperempuanbaliasliuntukmencapaipeningkatan.

kaumperempuansenantiasatermarginalkanbaiksecarafisikmaupunpsikologi.Namun tengahdilematersebut,

bahwakaumwanitabaliaslimenerimamarginalisasitersebutsecarasadardanalamiah. proses

Dalamkonteksini,

di tengah-

dapatdiketahui,

Hal 
initidakbisadilepaskandarisistemnilaibudayamasyarakatbaliasli yerorientasireligiokosmossehinggamenempatkanorientasinilaipolitisperempuan paling rendahsetelahnilai-nilaireligius, sosial-ekonomis, danotonomisasisebagaisebuahrepublik. (4) Desa adat sebagai simbolisme tertinggi dalam tataran masyarakat bali asli, secara struktural belum melakukan aktivitas nyata dalam kaitannya dengan pendidikan politik pada kaum wanitanya. Hal ini tidak bisa dilepaskan dari adanya sebuah dogma patriarkhi yang memang telah melekat pada kedirian desa adat bali asli. Pada sisi lain, dalam kehidupan masyarakat bali asli, sudah mulai adanya keterbukaan, khususnya pada kaum mudanya, dimana kaum wanita telah mulai berani keluar dari patron patriarkhi, seperti dalam penentuan pilihan saat pemilu atau pemilihan kepala desa. (5) Secara permanen tidak ada perbedaan yang signifikan antar lokasi penelitian dalam kaitannya dengan model sensitisasi dan penyadaran gender, karena secara sosiologis antara desa adat bali asli memiliki kesamaan idiologis secara budaya, sehingga budaya patriarki telah menjadi bagian integral dalam aktivitas sosial dan politiknya. Namun disisi lain, dalam kaitannya dengan penguasaan sumber daya manusia, atau modalitas keluarga, kaum wanita diberikan porsi tertentu secara dominatif, seperti mengurusi anak, kegiatan spiritual keluarga, menyame braya, dan kegiatan lainnya yang mendukung kelelakian suaminya di mata desa adat. Proses pembentukkanmasyarakatmadani Indonesia, dalamhubungannyadengantujuandankarakteristikmasyarakatDesaAdatbaliasliternyatacukuprelevandala mmenciptakaniklimkesetaraan gender.

\section{Referensi}

Abbas, A. (2006). Kesetaraan gender dan pergulatan sosial-ekonomi masyarakat pedesaan. Denpasar: PT. Pustaka Bali Post.

Anderson, B. (1989). Imagined Community (Komunitas-KomunitasTerbayang). Jakarta: Insist

Ansyar, L (2006). Kebebasan Wanita Tahrirul-Ma'rah fi 'Ashrir-Risalah (penerjemah: Drs. As'ad Yasin). Jakarta: Gema Insani Press.

Ardita, G.P. (2005). Kedudukan dan Peranan Wanita dalam Lembaga Politik. (Laporan Penelitian). Denpasar: Universitas Udayana.

Arga, I.M. (2003). Perempuan Bali dan Pola Ketergantungan Politik", Citra Wanita dan Kekuasaan. Surabaya: Obor Jaya.

Bagus, D.G. (2001). A Study on Customs Pertaining to Twins in Bali. New York: Columbia University Press.

Bawa, A (2006). Bali Pada Era Globalissai Pulau Seribu Pura Tidak Seindah Penampilannya. Yogyakarta: LkiS.

Bae, D. J. (2002).Gender and Politicant Participant. USA: Open University

Branson, G.M., dkk (ed). (2007). Perempuan Indonesia : Dulu dan Kini, Jakarta, PT Gramedia Pustaka Utama.

Costa, A.T. (2003).The Female World. New York: The Pree Press.

Carspecken, P.F. (1996). Critical Ethnography in Educational Research: A Theoritical and Practical Guide. New York and Londen: Routledge.

Farisa, A. (2006). Wanita Indonesia dan Kesempatan Pengembanagn Karis dalam Dunia Pendidikan Tinggi. Jogjakarta: LP3IS Press.

Foster, Nick. (2003). " A case Study of Women Academics, Views on Equal Opportunities Career prospects and Work-Family Conflicts in A British University", Women in Management Review, vol 15. no.7, pp. 316-330.

Harsiwi, T.A.M. dan B. Linggar Yekti N, (2003). Kesetaraan Kesempatan, Prospek Karir, dan Konflik KerjaKeluarga Akademisi Wanita pada Perguruan Tinggi Swasta di Kopertis Wilayah V Daerah Istimewa Yogyakarta dan Kopertis Wilayah VI Jawa Tengah, (Hasil Penelitian Kajian Wanita), Direktorat Jenderal Pendidikan Tinggi, Departemen Pendidikan Nasional.

Hunterwill, J. (2007). The Grand Theory of Politic. USA: McMilland, co.

Ibran, T.O. (2005). KajianWanitadalam Pembangunan. Jakarta: YayasanOborIndonesia.

Kaler, I. G. K. (2003). Butir-butir Tercecer tentang Adat Bali Jilid I. Denpasar: Bali Agung.

Kantor Menteri Negara Kependudukan dan Lingkungan Hidup. (2001). Mobilitas Tenaga Kerja Wanita di Indonesia. Jakarta

Lasmawan, I.W. (2005). Perempuan Malam di Kota Singaraja: Studi Eksploratif terhadap penjaja seks komersial di Kota Singaraja: (Laporan Penelitian). Undiksha.

Lasmawan, I.W. (2006). Eksistensi Wanita dalam Struktur Masyarakat Tradisional Bali. (LaporanPenelitian). Undiksha

Lausiana, R. (2005), “Jobs and Gender : How are Women Doing”, University Publication Office, Hongkong, didownloaddariwww.cityu.edu.hkpadatanggal 10 Maret 2002. 
56Jurnal PenelitiandanPengembaganSainsdanHumaniora, Vol1(2)Oktober 2017, h. 51-56

Lubis, M.W. (2005). "Situation of Women in Scientific Research in Australia : Equal Opportunity is Not a Strong Enough Tool", Melbourne, Australia.

McTitto, C. (2005). "Adat and Dinas: Village and State in Contemporary Bali". DalamHildred Geertz (ed), State and society in Bali. Leiden : KLTLV Press. 